UDC 159.922

\title{
Ostapovych Volodymyr,
}

Candidate of Juridical Sciences, Chief

of the Research Laboratory, State

Research Institute MIA Ukraine,

Kyiv, Ukraine

ORCID ID 0000-0002-9186-0801

\section{LEGAL AND PSYCHOLOGICAL PECULIARITIES OF ORGANIZATION OF PSYCHOPROPHYLACTIC WORK BY THE HEADS OF THE NATIONAL POLICE UNITS OF UKRAINE}

The article is devoted to the disclosure of psychological conditions for the head of the effective psychoprophylactic work with the staff of police units. Work experience of police managers of developed foreign countries testifies to the growing attention to the study of psychological factors of the effectiveness of police work, creation of conditions for the preservation of physical and psychological health of staff, carrying out psychoprophylactic work. Policing is a complex, physically and psychologically demanding activity, often involving threats to the lives and health of police officers.

The article focuses on the fact that modern concepts of police management are based on the idea of a proactive approach, which should provide psychological prevention of problems in the police organization, prevention of conflicts, stress, dissatisfaction of employees and the like. It has been established that the psychological conditions for the implementation of such proactive management are the implementation by the head of the humanistic personally-oriented approach to police officers; organization of effective teamwork and leadership in units; motivation and stimulation of the work of police officers, their self-devevopment. Precisely the proactive approach to management ensures high efficiency of work of police units, ensuring preservation of their physical and psychological health. 
The article demonstrates that for the purpose of its implementation it is important to carry out special professional and psychological training of police managers aimed at developing skills of preventive work with staff, moreover, an effective means of such preparation is the introduction of professional training of police officers in the practice of professional technology of professional-psychological training.

Keywords: psychological conditions, psychoprophylactic work, police, heads, professional-psychological training.

\section{REFERENCES}

1. Barko V.I., Zelenyi V.I., Irkhin Yu.B. (2009) Robocha knyha kerivnyka orhanu vnutrishnikh sprav (psykholoho-pedahohichnyi aspekt). "Working book of the head of the internal affairs body (psychological and pedagogical aspect)": textbook. Vinnitsa: Knyha-Vega; Vinnytsia. region print. 248 p. [in Ukrainian].

2. Zhuravlev A.L. (1993) Kommunykatyvnye kachestva lychnosty rukovodytelia y effektivnosti rukovodstva kollektivom. "Communicative qualities of the personality of the leader and the effectiveness of team leadership". Psychology issues. No. 1. P. 57-67. [in Russian].

3. Muchynsky P. (2004) Psykholohyia, professyia, karyera. "Psychology, profession, career". 7th ed. St. Petersburg: Peter. 593 p. [in Russian].

4. Meskon M.Kh., Albert M., Khedoury F. (1992) Osnovy menedzhmenta. "Fundamentals of management": Transl. from English M.: Delo. 702 p. [in Russian].

5. Svon R.D. (2000) Effektivnost pravookhranitelnoy deiatelnosti i eye kadrovoye obespecheniye v SShA i Rossii. "The effectiveness of law enforcement and its staffing in the United States and Russia”. St. Petersburg: Aletheia. 296 p. [in Russian].

6. Charlz M.T. (2000) Sovremennoye sostoianye y perspektivy professionalnoi podhotovki sotrudnykov politsi (militsii) SShA i Rossii. Sankt-Peterburh: Aleteiia. 268 p. [in Russian]. 